\title{
Glacier 'retreat' threatens Alaskan oil tanker route
}

A MAJOR glacier is threatening to disrupt the transportation of oil from Alaskan oil-fields by discharging large masses of ice into the shipping route used by supertankers, according to scientists of the US Geological Survey. The geologists have mounted a research effort into the state and behaviour of the 425-square-mile Columbia glacier, which discharges into Prince William Sound 40 kilometres from the end of the Trans Alaskan pipeline at Port Valdez.

They are concerned that the glacier could, as a result of changing climatic conditions, experience a 'drastic retreat' which might result in the discharge of about 50 cubic miles of ice over a period of 30-50 years-and consequently a major hazard to shipping. Coastguard officials admit that the dangers are "potentially very serious". They are already studying various contingency plans, in particular the use of a three-mile nylon cable to keep the icebergs out of shipping lanes.

Glaciologists have known for many years that glaciers, which normally deposit ice into the sea at a relatively slow rate through a process known as 'calving', can suddenly become unstable and discharge large amounts of ice over a relatively short period of time.

Only in recent years, however, since the route of the 800 -mile Alaskan pipeline was planned and agreed upon, have the climatic mechanisms leading glaciers to behave in this way begun to be understood. In particular, drastic retreats are thought to follow a period in which the glacier becomes thinner due to a temperature imbalance between the ice and the surrounding atmosphere. And this thinning is precisely what has been observed on the Columbia glacier, so far the only glacier along the Alaskan coastline which has not experienced a

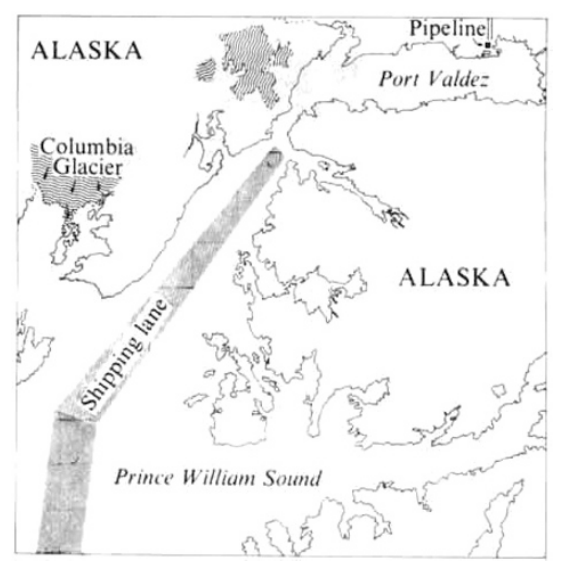

The threat to shipping lanes

drastic retreat in the past one thousand years.

Since 1974, when the possible implications were first pointed out by glaciologist Dr Austin Post, government geologists have been looking at the behaviour of the glacier. A current project to collect data during the year September 1977 to September 1978 at a cost of $\$ 800,000$ has involved considerable reallocation of

\section{A bad year for weather, a good one for climate}

\section{David Dickson discusses the initiatives contributing to a US programme for climate research}

Two SEvere winters and a period of prolonged drought in California have, like the proverbial hangman's noose, had a wonderfully concentrating effect on the collective minds of US political administrators.

The net result has been a major boost, both politically and financially, for climate research. And accompanying this has been a perceptible shift in the balance of research policy away from attempts to achieve increasingly accurate forecasting towards more general concerns over the nature and effects of climatic change.

The two houses of Congress have already passed broadly similar bills, the first going through the House of Representatives last autumn and the second passing through the Senate two weeks ago. With few differences separating the two sides, early agreement seems a distinct possibility, and a National Climate Program Act should be ready for the President's signature within a few weeks.

The administration has itself been developing a parallel initiative. In his Budget request for 1979 , presented to Congress in January, President Carter suggested the outlines for a broad inter-agency climate programme, based largely on the results of a study carried out last summer by an inter-agency panel reporting through Dr Frank Press, his science adviser.

Under these proposals, the total amount of money spent by the various agencies on climate issues would be increased from $\$ 75.7$ million in 1978 to \$104 million in 1979. And the Department of Commerce's National Oceanic and Atmospheric Administration (NOAA), would be the "lead agency" for such a programme.

Nor has the scientific community been slow to respond. The National Academy of Sciences has established a Climate Research Board under the chairmanship of Dr Robert White, a former director of NOAA. This will act as a focus for the climate interests of a wide range of NAS committees, and is already engaged in a study of the research efforts of the various government agencies.

The various developments now fitting together into a single picture are the result of a concern for climate which has been growing since the beginning of the decade, and of various political initiatives which originated in the Nixon era, but became bogged down because of Watergate.

In particular, they reflect a shared shift in philosophy-and hence in research methodology-away from a prime emphasis on meteorology and on achieving increasingly sophisticated and accurate weather forecasting, a field which many feel has failed to live up to early expectations.

(This failure has itself given rise to new strategies. Thus forecasters, for example, are increasingly expressing predictions in statistical terms, such as announcing that "the chance of precipitation tonight will be $100 \%$ ". And agriculturalists are shifting attention to the diagnosis of existing weather patterns and their likely impact on crop yields).

A second reason for the increased emphasis in climatic change has been a growing awareness of the effects of the interaction between social activities and the atmosphere. Climatologists such as Stephen Schneider at the National Center for Atmospheric Research, for example, have argued that, as the world moves close to the limits of its capacity for producing food, water and energy, so the apparently marginal effects of climate behaviour-such as the Sahelian drought or crop failures in India and the USSR-become correspondingly significant.

Concern at the long-term implications has therefore focused on two closely-related areas, in both of which the complexity of the problems is 


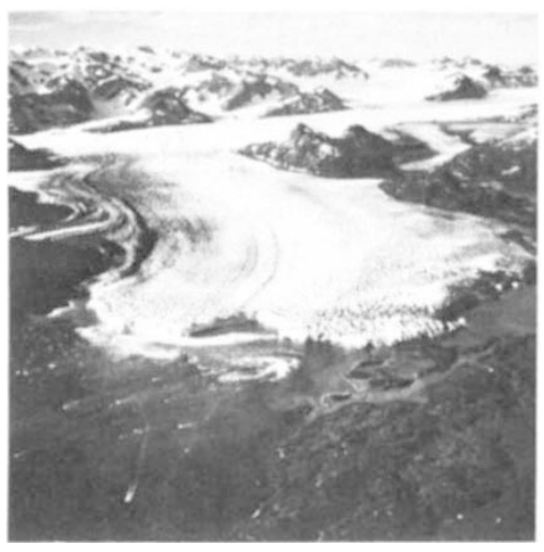

Columbia glacier: slipping into the sea

research funds within the US Geological Survey.

In a report which has just been published, the Department of the Interior says that last summer a considerable increase in the number of small icebergs deposited by the glacier into the shipping channel caused night-time shipping to be suspended during part of August. Commenting on the report, Dr Mark F. Meier, chief of the USGS glaciology project, said: "There is no evidence yet that the Columbia glacier has become unstable and begun a drastic retreat, but last summer's experience indicates that it needs to be watched closely."

According to Dr Meier, since 1975 iceberg discharge has increased from one summer to the next, while the altitude of the ice surface near the discharge point decreased by more than 30 feet between 1976 and 1977

"This may mean that a drastic retreat is imminent," he says.

The geologists claim that one reason the glacier has not retreated so far is that its front end rests on a raised edge, behind which the glacier is thought to be as much as 2,000 feet deep for up to 20 miles.

"If huge icebergs do form, the water over the moraine where the glacier rests is so shallow that the larger icebergs will be unable to leave the embaymeny. These large bergs would break up into smaller bergs which could then escape," according to Dr Meier. Such icebergs could, given winds from the appropriate direction, float into the shipping lanes; the scientists claim that this would raise the hazards to shipping by a factor of 10 or even 100 times.

The US coastguard has been discussing various contingency plans, the most feasible of which appears to be a proposal to restrain the icebergs using a bundle of 13 nylon ropes, each 10 inches in diameter. Such a project would, it is estimated, cost $\$ 30$ million; but it is pointed out that this is less than the market value of three days' supply of oil from the end of the pipeline.

So far the oil companies have, in public at least, adopted a 'wait and see' attitude. A spokesman for Alyeska, the firm which operates the pipeline, said last week that the glaciologists predictions remained theoretical and speculative, and that the company saw "no evidence" that a major retreat was imminent. However, the spokesman admitted that if such an event did occur, then it might present a major problem to the orderly transport of oil from the Alaskan fields.

David Dickson

\section{Sorry, for copyright reasons some images on this page may not be available online}

The effects of extreme weather: Hood and drought

reflected in the amount of research needed to tackle them: the impact of human activity on climate change, and conversely the impact of such change on human activity.

"The effects of social activity on the climate is an area which we still know very little about," says Dr Francis Bretherton, director of NCAR, a research centre run jointly by 40 universities primarily on National Science Foundation funds.

"In some areas, physical scientists are making a lot of assumptions which are almost certainly wrong. There are many important questions concerning the trace chemistry of the oceans and the atmosphere, for example about the carbon, nitrogen and sulphur cycle on which much basic research remains to be done."

Similar needs are also being recognised in climate dynamics, until recently a relatively neglected field. And in a recent report on research strategy for the US climate programme, the US Committee for the Global Atmospheric Research Programme (GARP) suggested that high priority be given to detailed studies of the annual cycle of the atmosphere and its lower boundaries.

The future of funding in universities for climate research looks promising. Admittedly the increase in the National Science Foundation's budget for climate research requested by the President for 1979 is not as large as for other agencies; however these have been told that a significant proportion of their research funds must be spent in universities.

There remains one area of uncertainty: the scientific and political strategies that should be adopted for assessing the impact of climate change on social activity-and thus on policy formulation.

Related directly to this is the problem of co-ordinating the research programmes of a number of different agencies. While pursuing different mandates, each is required to tackle issues that involve a complex measure of science and technology with fiel̂ds such as geography, ecology, agronomy, economics, political science and even anthropology.

The congressional point of view is that the philosophy of a national climate programme should essentially be "user-pull" rather than "researcherpush". In line with this, both of the current bills suggest that prime responsibility should rest with the head of the lead agency (in the Senate Bill the head is explicitly stated to be the Secretary of Commerce, responsible for NOAA). 


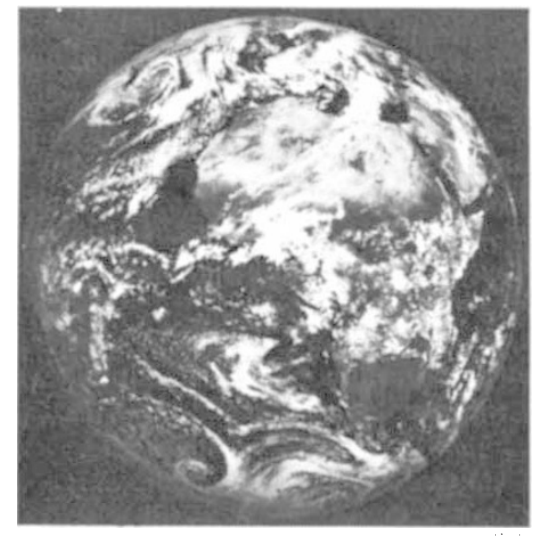

METEOSAT

Cloud patterns seen by satellite

Many scientists, however, fear the problems that could arise from interagency disagreements over who should take responsibility for what. This has, for example, happened in the past in disputes between the Departments of Agriculture and the National Aeronautic and Space Administration over crop forecast programmes, or the Department of Energy's involvement in assessing the impact of $\mathrm{CO}$ emission.

Such concern is reflected in a report on the two versions of the proposed legislation which has been prepared by the President's National Advisory Committee on Oceans and Atmosphere (NACOA), an independent body responsible to both the President and Congress.

It is concerned primarily with showing how the similar versions of a climate bill could be relatively easily reconciled and also suggests that the President's science adviser, the director of the Office of Science and Technology Policy, should have prime responsibility for co-ordinating the programme and its budget.

"This will ensure considerations of the programme as a coherent executive branch activity, rather than as an effort shaped largely by the policies of any one agency," the NACOA report states.

OSTP is said to be less than happy with this proposal, partly because of a lack of sufficient resources and other pressures of work. Unlike most of the other suggestions made by NACOA, such as they are, that university research on climate issues of national importance should be $100 \%$ federally funded, this one will not be taken up fully into the legislation, although OSTP may be given formal responsibility for the programme.

Much will therefore depend on the individual who is selected to head the climate programme, and whether he or she has the skills and status to overcome interagency differences. But like the weather itself, political forecasting is an unpredictable activity.

David Dickson

\section{New head of French research appointed}

In APPOINTING Pierre Aigrain to head French scientific research, the government of M. Raymond Barre has chosen a scientist rather than a technocrat or politician. He is already well known in scientific research in France.

Aigrain started off specialising in electronics and initiated the study of semiconductors in France. He later travelled widely, finding out about the organisation of research in other countries. Returning to France, he showed his versatility by alternating between applied science, fundamental research and higher education, working for the National Centre for Scientific Research (CNRS), the Collège de France, the École Normale Superieure, the Faculty of Science and the Atomic Energy Authority. From 1968 to 1973 he was general adviser on scientific and technical research, a position close to the Prime Minister.

So far, Aigrain's research policy is unknown, if only because he has not yet named his advisers. But it is worth noting that from 1973 he was scientific organiser in the Giscard group 'Perspective and reality', and that he succeeded Barre on 1 March, 1977 as chief of higher scientific study. It is likely that, as well as following the priorities defined in the Grand Plan, the new Secretary of State for Research will reflect on the advice given last year by the consultative committee on technical and scientific research (CCRST). It pinpointed the following problems:

- The necessity for a strong scientific and technical research policy.

- The need for more freedom of choice in applied science, combined with a long term industrial strategy (an area in which Aigrain should have many ideas; he was technical directorgeneral with the Thomson CSF Company until his government appointment).

- The decline in productivity of research workers.

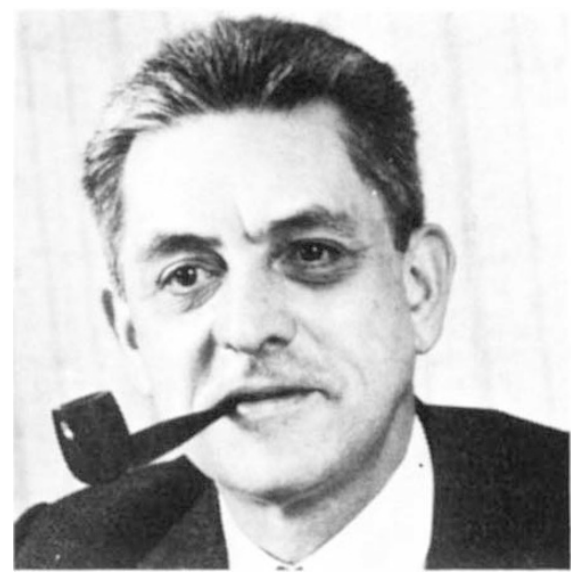

Pierre Aigrain: scientist not technocrat

Finally, the CCRST report says it is important to put right the imbalances in French scientific research, such as the erosion of fundamental research and industrial research, limited international cooperation, and the lack of support in areas like bio-medicine, bioagronomy, oceanology and new forms of energy.

\section{Soviets rap birch-sap tappers}

BIRCH-SAP tapping is a traditional spring-time delight among the east Slavs, indeed, the Byelorussian and Ukrainian words for 'March' seem derived from this practice. Although the careful sap-drinker, wishing to conserve his supply of the juice (which may be compared with maple syrup), would always take care to close the 'wound' after tapping, heedless tapping can result in the loss of the tree Havoc is being wreaked in Soviet birchforests.

Even in the last century, the Byelorussian didactic poet Jan Cacot found it necessary to include a warning against careless tapping in a collection of verses otherwise devoted to the virtues of work and the evils of hard liquor. Although birch-tapping has long since become a Soviet state monopoly, with private operations punishable by law, unskilled tappers are still about and are causing considerable loss of trees. In a recent radio interview,
Mikhail G. Chervonnyy, deputy head of the Chief Directorate for Forest Protection of the Russian SFSR explained that "it is no secret" that many saploving "tourists" attack the trees indiscriminately with axes, so that the tree of ten perishes through loss of sap. The state-appointed experts, of course, use special techniques which do not harm the tree.

Chervonnyy explained the proper procedure: the incision must be made by a $2-\mathrm{cm}$ drill, to a depth of up to $3 \mathrm{~cm}$, and not higher than $30 \mathrm{~cm}$ from the ground. After sap-running is completed, the incision must be closed by a special putty. Unfortunately the talk rather took the form of an instruction course for the sap-poacher. One can only wonder if, finding it impossible to stop illegal tapping, the Directorate had decided on this somewhat pragmatic method of preventing permanent damage to the trees. 